\title{
Effects of cortisol on the expression of interleukin-6 and interleukin-1 $\beta$ in human osteoblast-like cells
}

\author{
D Swolin-Eide and C Ohlsson
}

Research Center for Endocrinology and Metabolism, Department of Internal Medicine, Sahlgrenska University Hospital, S-413 45 Göteborg, Sweden

(Requests for offprints should be addressed to D Swolin-Eide)

\begin{abstract}
High levels of glucocorticoids are believed to alter bone remodeling by decreasing bone formation and increasing bone resorption. It has been suggested that different cytokines, like interleukin-6 (IL-6) and interleukin-1 (IL-1), are involved in bone resorption by activating immature osteoclasts, and some studies indicate that IL-6 promotes bone formation by a mitogenic effect on osteoblasts. The aim of the present investigation was to study whether cortisol regulates the expression of IL- 6 and IL-1 $\beta$ in human osteoblast-like cells.

A high dose of cortisol $\left(10^{-7} \mathrm{M}\right)$ decreased, as expected, the C-terminal propeptide of type I collagen released into the culture medium. The IL- 6 mRNA levels and IL-6 protein released into the culture medium were also decreased by cortisol in a dose-dependent manner.
\end{abstract}

\section{Introduction}

Back in 1932, Cushing reported that increased levels of glucocorticoids cause osteoporosis and increase the risk of bone fractures. Osteoblasts express receptors for glucocorticoids (Chen et al. 1979) and it is well known that high levels of cortisol decrease the proliferation and expression of differentiation markers in rodent and human osteoblasts (Canalis \& Avioli 1992, Jonsson et al. 1993, Delany et al. 1995). One of the mechanisms involved in the negative effect of high levels of cortisol on bone metabolism is therefore to decrease bone formation via direct interaction with the osteoblasts.

Another possible mechanism by which cortisol regulates bone remodeling is modulation of bone resorption. Cortisol increases bone resorption in tissue cultures of mouse calvaria (Conaway et al. 1996). Interestingly, osteoblasts are involved in the differentiation and activation of osteoclasts (Takahashi et al. 1988). The mechanism for this osteoblast-induced osteoclast activation is not yet fully understood. It has been suggested that cytokines such as interleukin-6 (IL-6) and interleukin-1 (IL-1) take part in this process. IL-6 is a multifunctional cytokine exerting a variety of well-established effects, including B- and T-cell activation, stimulation of fever and release of acute-phase
The maximum effect was seen at $1 \mu \mathrm{M}$ cortisol (mRNA $23 \cdot 1 \pm 7 \cdot 9 \%$ of control culture; protein $28 \cdot 2 \pm 8 \cdot 3 \%$ of control culture). The decrease in IL-6 mRNA levels was apparent $4 \mathrm{~h}$ after the addition of cortisol and was still present $20 \mathrm{~h}$ later. The decrease in IL-6 protein released into the culture medium was seen $20 \mathrm{~h}$ later than the decrease in IL- 6 mRNA levels. The production of IL-1 $\beta$ protein released into the culture medium was decreased in a dose-dependent manner after the addition of cortisol with a maximum effect at $1 \mu \mathrm{M}$. The effect of cortisol on IL-1 $\beta$ protein released into the culture medium was seen $16 \mathrm{~h}$ after the addition of cortisol.

To summarize, cortisol decreases the expression of IL-6 as well as IL-1 $\beta$ in human osteoblast-like cells.

Journal of Endocrinology (1998) 156, 107-114 response proteins (Van Snick 1990, Kopf et al. 1994). Furthermore, IL-6 is released from osteoblasts and bonemarrow stromal cells and is involved in bone resorption by activating immature osteoclasts (Ishimi et al. 1990, Kurihara et al. 1990, 1991, Black et al. 1991).

IL-6 interacts with a specific membrane-bound receptor, IL-6R (Kishimoto et al. 1992). There is also a soluble IL-6R (sIL-6R), which is proteolytically cleaved from the membrane-bound IL-6R. It has been shown that the biological activity of IL-6 results from the direct association of either the sIL-6R/IL-6 complex or the IL-6R/IL-6 complex with the membrane-associated protein, gp130, which transduces the IL-6 signal (Mackiewicz et al. 1992, Gabay et al. 1995). Furthermore, it has been reported that sIL-6R triggers osteoclast formation by IL-6, indicating that the amount of sIL-6R may modulate the IL-6 effect (Tamura et al. 1993).

IL-1 is a term for two polypeptides (IL-1 $\alpha$ and IL-1 $\beta$ ) which are involved in inflammatory, metabolic, hematopoietic and immunological properties (Dinarello 1991). IL-1 is also involved in bone resorption (Gowen et al. 1983), and the so-called human osteoclast-activating factor was found to be identical with IL-1 $\beta$. Furthermore, IL-6 expression in osteoblasts is induced by IL-1 (Ishimi et al. 1990). 
In mouse osteoblasts, IL-6 levels are decreased after stimulation with dexamethasone (Feyen et al. 1989), and one study, in which the effect of one dose of dexamethasone $\left(10^{-6} \mathrm{M}\right)$ was tested, indicated that dexamethasone decreases IL-6 expression in human osteoblasts (Littlewood et al. 1991). The aim of the present study was to investigate more thoroughly the dose-response effects and time-course effects of cortisol on IL-6 expression in human osteoblast-like (hOB) cells and to see whether IL-1 $\beta$, a known regulator of IL-6 production, or sIL-6R, a proposed modulator of the IL-6 effect, is regulated by increased levels of cortisol.

\section{Materials and Methods}

\section{Cell culture}

The isolation and culture of hOB cells has been described previously (MacDonald et al. 1984, Nilsson et al. 1995). Trabecular bone was obtained from orthopedic surgery; the samples were dissected into small pieces and washed extensively in F12 (Gibco, Paisley, Scotland, UK). Subsequently, the bone chips were transferred to $75 \mathrm{~cm}^{2}$ or $162 \mathrm{~cm}^{2}$ culture flasks (Costar, Cambridge, MA, USA) and cultured in Dulbecco's modified Eagle's medium (DMEM)/F12 (1:1, v/v) (Gibco) containing 10\% (v/v) fetal calf serum (FCS; Harlan Sera Lab Ltd, Sussex, UK), fungizone (500 $\mu \mathrm{g} / \mathrm{l}$; Gibco), gentamycin sulphate (50 mg/l; Sigma, St Louis, MO, USA), L-glutamine (2 mmol/l; Gibco) and L-ascorbic acid (100 mg/l; Merck, Darmstadt, Germany) in a humidified 5\% $\mathrm{CO}_{2}$ atmosphere at $37^{\circ} \mathrm{C}$. Isolating hOB cells this way results in a certain amount of heterogeneity. Therefore the cells are referred to in the literature as osteoblast-like cells. This should be borne in mind when interpreting results obtained. When the effect of cortisol was tested, the hOB cells were starved in DMEM without phenol red (Gibco) with the addition of $0.5 \%$ dextran-coated charcoalstripped FCS (DCC-FCS) (kindly provided by M Slootweg, Eli Lilly, Nieu Wegein, The Netherlands) for 24-30 h, followed by the addition of cortisol (hydrocortisone, H-0135, lot 44H9402,115H4629; Sigma) for 0.5$24 \mathrm{~h}$. Cortisol was dissolved in absolute ethanol and diluted 1:1000 or more in the culture medium. Recombinant human (rh)IL-Ia (Boehringer Mannheim Biochemica, Mannheim, Germany; lot 14782820) was added to the cells at the time of cortisol addition in some experiments. Endotoxin levels in the culture medium (DMEM/F12, 1:1) and phenol-free DMEM were 0.5 and $0 \cdot 14$ European units $(\mathrm{EU}) / \mathrm{ml}$ respectively (according to Gibco/BRL). The endotoxin levels were $1.2 \mathrm{EU} / \mathrm{ml}$ (Harlan Sera Lab) in $100 \%$ serum (FCS) and $0 \cdot 1 \mathrm{EU} / \mathrm{ml}$ in $10 \%$ serum $(10 \%$ FCS was used for culturing the cells before the experiment). The endotoxin levels were $4.8 \mathrm{EU} / \mathrm{ml}$ (Department of Microbiology at Sahlgrenska University Hospital, Göteborg, Sweden) in 100\% DCC-FCS and 0.02 EU $/ \mathrm{ml}$ in $0.5 \%$ DCC-FCS $(0.5 \%$ DCC-FCS was used for culturing during the experiment). Cells were routinely tested and found to be negative for mycoplasma infections. In experiments in which human (h)IL-6 protein and hIL-1 $\beta$ protein were measured, cells were grown in 24-well tissue culture dishes (Costar).

The study was approved by the ethical committee at Sahlgrenska University Hospital in Göteborg.

\section{Preparation of nucleic acid}

Total nucleic acids were prepared as described by Durnam \& Palmiter (1983), and RNA was prepared by the method of Chomczynski \& Sacchi (1987).

Probe

A $412 \mathrm{bp}$ fragment of exons 2-5 of the hIL-6 gene subcloned into a pCRII vector was used (Swolin \& Ohlsson 1996). A labeled IL-6 antisense RNA probe was generated with Sp6 polymerase from an Xhol-linearized plasmid, and IL-6 sense RNA was generated with T7 polymerase from a HindIII-linearized plasmid.

\section{RNase protection solution hybridization assay}

Total nucleic acids for the RNase protection solution hybridization assay were prepared by homogenizing harvested hOB cells with a Polytron in buffer containing $1 \%$ (w/v) SDS, $20 \mathrm{mmol}$ Tris- $\mathrm{HCl} / \mathrm{l}(\mathrm{pH} \quad 7 \cdot 5)$ and $4 \mathrm{mmol}$ EDTA/l. The homogenized cells were then digested by overnight proteinase- $\mathrm{K}$ treatment, and total nucleic acids were prepared by a subsequent phenolchloroform extraction, as described by Durnam \& Palmiter (1983). The RNase protection solution hybridization assay was then performed as described by Mathews et al. (1986) (intra-assay coefficient of variation (CV) 14.9\%). Protected RNA-RNA hybrids were precipitated with trichloroacetic acid, collected on glass-fiber filters and counted in a scintillation counter. The signal was compared with a standard curve obtained by hybridization to known amounts of sense IL-6 RNA. The RNase protection solution hybridization assay, used for quantification of IL-6 mRNA, correlates the amount of IL- 6 mRNA with the DNA content. Thus the results are finally given as pg sense IL-6 RNA standard/ $\mu \mathrm{g}$ DNA. The advantage of presenting the results in this way is that the absolute number of transcripts per cell is obtained. The disadvantage of correlating the mRNA levels with DNA instead of RNA is that there is a risk that the observed effect of a factor which regulates most mRNAs is related to multiple rather than single effects. To avoid this, control experiments were performed in which the effect of cortisol was correlated with RNA (see RNase protection assay followed by gel separation below). DNA analysis was performed as described by Labarca \& Paigen (1980). 
RNase protection assay followed by gel separation

For the RNase protection assay followed by gel separation (RPA II kit; Ambion, Austin, TX, USA), $10 \mu \mathrm{g}$ total cellular RNA were hybridized at $45^{\circ} \mathrm{C}$ overnight with ${ }^{35}$ S-labeled human IL-6 riboprobe, then digested with RNase. The RNA-RNA hybrids were precipitated, resuspended and separated on a $6 \%$ Tris/boric acid/EDTAurea gel (Novex, San Diego, CA, USA). Signal from protected fragments was quantified using a PhosphorImager (Molecular Dynamics, Sunnyvale, CA, USA).

\section{ELISAs}

An hIL-6 ELISA was used to measure IL-6 released into the medium (D 6050; R\&D Systems, Abingdon, Oxon, UK). A human ELISA was used for measuring hsIL-6R released into the medium (DR 600; R\&D Systems). hIL-1 $\beta$ was measured by using a human high-sensitivity ELISA (HSLB50; R\&D Systems). Intra-assay CV values were assessed by measuring 20 individual replicates of the same sample in one assay. Interassay $\mathrm{CV}$ values were assessed by measuring samples in duplicate on 20 different occasions. The mean of the duplicate was calculated on each occasion and the means from 20 different assays were then used for CV calculations (R\&D Systems). Thus means of duplicates were used instead of single readings for the interassay $\mathrm{CV}$ values. This method of calculating interassay CV values actually underestimates them, which explains why some were lower than the corresponding intra-assay CV values. The intra-assay CV values for hIL-6 at $15 \cdot 8,95 \cdot 6$ and $179 \mathrm{pg} / \mathrm{ml}$ were $4 \cdot 4,3 \cdot 1$ and $1 \cdot 7 \%$ respectively, and the interassay $\mathrm{CV}$ values at $16 \cdot 4,98 \cdot 8$ and $188 \mathrm{pg} / \mathrm{ml}$ were $3 \cdot 6,2 \cdot 5$ and $1 \cdot 9 \%$ respectively. All samples for hIL-6 measurements were diluted to a concentration of between 18 and $180 \mathrm{pg} / \mathrm{ml}$. The intra-assay CV values for sIL-6R at 134, 644 and $1669 \mathrm{pg} / \mathrm{ml}$ were $8 \cdot 6,2.6$ and $2 \cdot 3 \%$ respectively, and the interassay $\mathrm{CV}$ values at 130,645 and $1593 \mathrm{pg} / \mathrm{ml}$ were $6 \cdot 4,4 \cdot 2$ and $4 \cdot 7 \%$ respectively. The intra-assay CV values for hIL-1 $\beta$ at $12 \cdot 6$, $30 \cdot 4$ and $192 \mathrm{pg} / \mathrm{ml}$ were $2 \cdot 4,3 \cdot 4$ and $3 \cdot 4 \%$ respectively, and the interassay CV values at 30.8, 120 and $194 \mathrm{pg} / \mathrm{ml}$ were $7 \cdot 1,3 \cdot 4$ and $4 \cdot 1 \%$ respectively. The concentration of samples for hIL-1 $\beta$ measurements were between $12 \mathrm{pg} / \mathrm{ml}$ and undetectable levels. The antibody used for hIL-1 $\beta$ measurements has no cross-reactivity with hIL- $1 \alpha$. The sensitivities for the hIL-6, sIL-6R and IL-1 $\beta$ ELISAs were $0.7,3.5$ and $1.0 \mathrm{pg} / \mathrm{ml}$ respectively, and were determined by adding two standard deviations to the mean optical density values of 20 zero-standard replicates and calculating the corresponding concentration (R\&D Systems).

In preliminary studies, we correlated IL-6 and IL-1 $\beta$ levels with the number of cells. Short-term cortisol $(1 \mu \mathrm{M})$ treatment for $16 \mathrm{~h}$ (the time used in the experiments) did not alter the number of cells $(99 \cdot 7 \pm 15 \cdot 2 \%$ of control culture) and there was no difference between the effect of cortisol on cytokine production per cell and the effect of cortisol on cytokine concentration in the culture medium. Therefore no correlation with the number of cells was attempted in the rest of the experiments.

\section{C-terminal propeptide of type I collagen (PICP)}

PICP was measured (Department of Clinical Chemistry, Sahlgrenska University Hospital, Sweden) in 1:5 diluted cell medium from hOB with an RIA kit (Orion Diagnostica, Espoo, Finland) with an intra-assay $\mathrm{CV}$ of $3 \cdot 2 \%$.

\section{Statistical procedure}

Values are given as means \pm S.E.M. The statistical significance of differences between means was calculated using ANOVA followed by Student-Newman-Keul's multiple range test.

\section{Results}

PICP released into the culture medium decreased after cortisol $\left(10^{-7} \mathrm{M}\right)$ treatment $(19 \cdot 9 \pm 2 \cdot 7 \%$ lower than controls in pooled samples from two patients (males 22 and 32 years old)), demonstrating that our hOB cell cultures respond to cortisol in a manner similar to that previously described (Jonsson et al. 1993). To investigate the specificity of the IL-6 probe used in the RNase protection solution hybridization assay, RNase-protected probe fragments were analyzed on denaturating polyacrylamide gels. A protected fragment of the expected size, 412 bases, was detected in the mRNA from hOB cells (Fig. 1).

Cortisol decreased the levels of hIL- 6 mRNA in hOB cells in a dose-dependent manner $\left(10^{-7} \mathrm{M} \mathrm{34} \cdot 4 \pm 15 \%\right.$ of control culture and $10^{-6} \mathrm{M} 23 \cdot 1 \pm 7 \cdot 9 \%$ of control culture. A reduction in hIL-6 mRNA levels was seen $4 \mathrm{~h}$ after the addition of cortisol $(1 \mu \mathrm{M})$ and the effect was still present $20 \mathrm{~h}$ later (Fig. 2).

To investigate whether the effect of cortisol on IL-6 mRNA levels corresponded to the amount of IL-6 protein released into the medium an hIL-6 ELISA was used. The amount of IL-6 protein released into the culture medium decreased after stimulation with $1 \mu \mathrm{M}$ cortisol $(28 \cdot 2 \pm 8 \cdot 3 \%$ of control culture; Fig. 3). When IL-1 $\alpha$ $(25 \mathrm{U} / \mathrm{ml})$ was added to the culture medium, the release of IL-6 protein was sharply increased. However, in the IL-1 $\alpha$-stimulated cells, cortisol also decreased the amount of IL-6 protein secreted into the culture medium in a dose-dependent manner (at $1 \mu \mathrm{M} 12 \cdot 6 \pm 3 \cdot 4 \%$ of control culture; Fig. 3). Significant inhibition by cortisol of the amount of IL-6 protein secreted into the culture medium was seen $20 \mathrm{~h}$ later than the inhibitory effect on hIL6 mRNA levels (Fig. 2). 


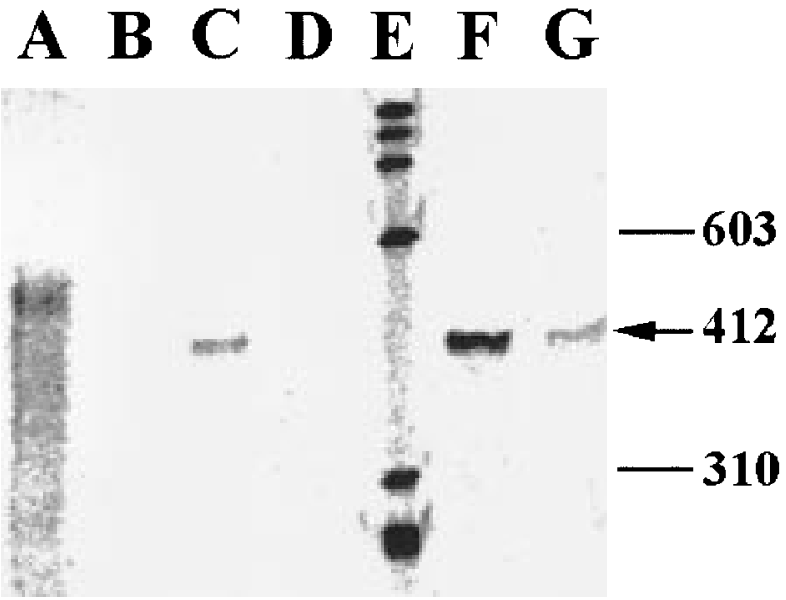

Figure 1 RNase-protected human IL-6 mRNA from hOB cells were analyzed by PAGE. Cells were cultured in $10 \%$ FCS, starved in DMEM without phenol red with the addition of 0.5\% DCC-FCS for $24 \mathrm{~h}$ and then stimulated with cortisol $\left(10^{-6} \mathrm{M}\right)$ for $16 \mathrm{~h}$ before cell harvest. Lanes $C$ and $D$, cells from a 15-year-old female; lanes $\mathrm{F}$ and $\mathrm{G}$, cells from a 38-year-old female; lane $\mathrm{A}$, standard $30 \mathrm{pg}$; lane $\mathrm{B}$, standard $3 \mathrm{pg}$; lanes $\mathrm{C}$ and $\mathrm{F}$, unstimulated hOB cells; lanes D and G, cortisol-stimulated cells; lane E, Haelll ladder.

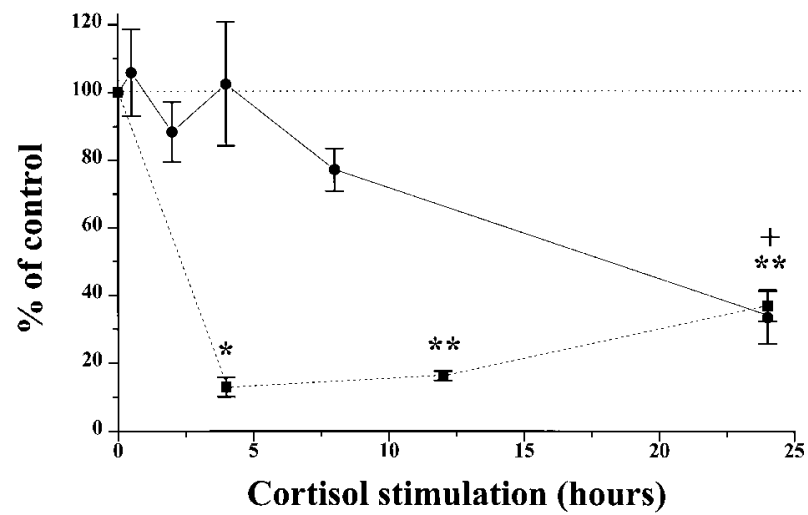

Figure 2 Time-course of the effect of cortisol on levels of hIL-6 mRNA ( $)$ and hIL-6 protein $(\bullet)$ released into the culture medium. Cells were cultured in $10 \%$ FCS, then starved in DMEM without phenol red with the addition of $0.5 \%$ DCC-FCS for a total period of $54 \mathrm{~h}$ and stimulated with cortisol $\left(10^{-6} \mathrm{M}\right)$ at different times before harvest. Each experiment was performed using cells from one patient. The results from two patients were then pooled. Values are expressed as \% of control (mean \pm S.E.M. from pooled samples from two patients (mRNA from a 29-year-old female and a 41 -year-old male; protein from two males, 28 and 50 years old)). ${ }^{*} P<0.05,{ }^{* *} P<0.01$ compared with untreated cells for mRNA; $+P<0.05$ compared with untreated cells for protein.

Basal levels of hIL-6 mRNA and hIL-6 protein secreted into the culture medium were measured in hOB cells from several subjects. No obvious correlation was found between IL-6 level and age (Fig. 4).

IL-1 $\beta$, a well-known stimulator of IL-6 production in hOB cells, was measured. The amount of hIL $-1 \beta$ protein secreted into the culture medium decreased in a dose-

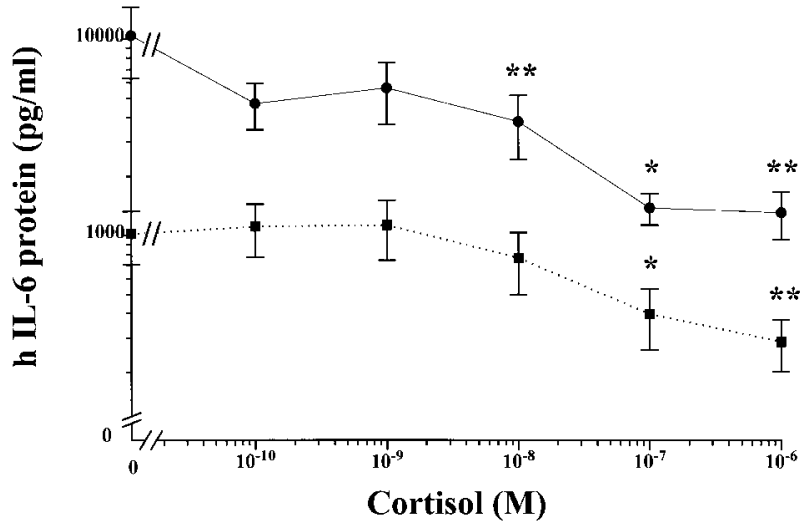

Figure 3 Dose-response effect of cortisol on hIL-6 protein secreted into the culture medium in cultured hOB cells from three patients (three males, 22, 32 and 47 years old). Cells were cultured in $10 \%$ FCS, starved in DMEM without phenol red with the addition of $0.5 \%$ DCC-FCS for $24 \mathrm{~h}$ and then stimulated with different doses of cortisol with $(\mathbf{0})$ or without $(\mathbf{\square})$ the addition of rhlL-1 $\alpha(25 \mathrm{U} / \mathrm{ml})$ for $16 \mathrm{~h}$ before harvesting of the medium. Each experiment was performed using cells from one patient. The results from three patients were then pooled. Levels are expressed as $\mathrm{pg} / \mathrm{ml}$. Values are the mean \pm S.E.M. ${ }^{*} P<0 \cdot 05,{ }^{* *} P<0 \cdot 01$ compared with cells not treated with cortisol.

dependent manner after the addition of cortisol with a maximum effect at $10^{-6} \mathrm{M}(2 \cdot 1 \pm 1 \cdot 2 \%$ of control culture; Fig. 5). hIL-1 $\beta$ protein was not detectable without the addition of rhIL-1 $\alpha(25 \mathrm{U} / \mathrm{ml}$; data not shown). Cortisol-induced inhibition of IL-1 $\beta$ was seen $16 \mathrm{~h}$ after the addition of cortisol (Fig. 6).

Furthermore, hsIL-6R released into the culture medium was measured. The protein could not be detected using an ELISA with a sensitivity of $3.5 \mathrm{pg} / \mathrm{ml}$ (six patients; data not shown).

\section{Discussion}

Bone metabolism is regulated by a balance between bone resorption by osteoclasts and bone formation by osteoblasts. In addition to being directly responsible for bone formation, osteoblastic cells control bone resorption by regulating the proliferation, differentiation and recruitment of osteoclast progenitors (Takahashi et al. 1988). It has been suggested that cytokines, such as IL-6 and IL-1, are involved in the physiological interaction between osteoblasts and osteoclasts. IL-6 is expressed at a high level in hOB cells compared with other human tissues (Swolin \& Ohlsson 1996). It could therefore be supposed that IL-6 exerts physiologically important effects in the regulation of bone remodeling in humans. In the present study, it is demonstrated that high levels of cortisol decrease IL-6 expression in hOB cells, and a possible mechanism via a reduction in IL-1 $\beta$ is investigated. 

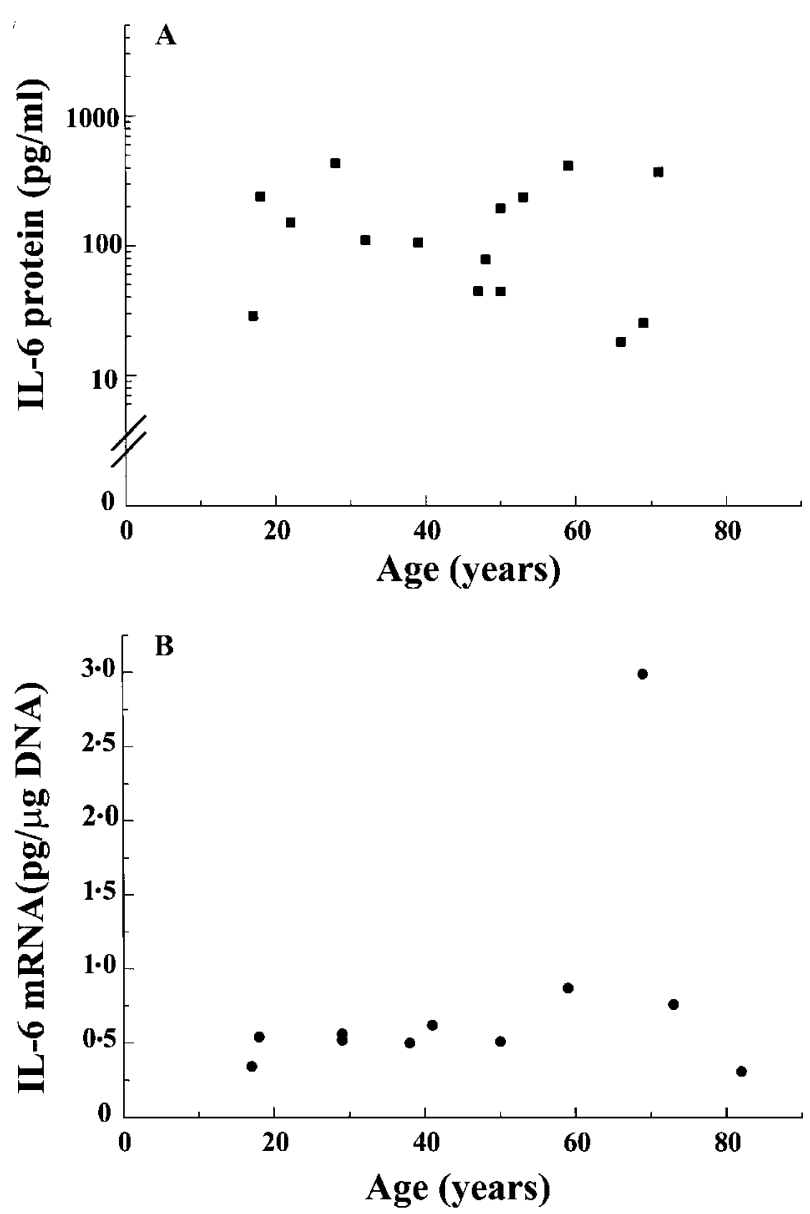

Figure 4 Levels of IL-6 protein released into the medium (A) and IL-6 mRNA (B) in hOB cells correlated with age of donor of hOB cells. No significant correlation was observed $(r=0 \cdot 38$ and $P=0 \cdot 25$ for IL-6 protein released into the medium, $r=0.02$ and $P=0.94$ for IL-6 mRNA).

Several hormones and growth factors regulate IL-6 expression in osteoblasts. Some studies demonstrate that estrogen, an anti-resorptive hormone, decreases osteoblastic IL-6 production (Girasole et al. 1992, Kassem et al. 1996), whereas growth hormone, vitamin D, tumor necrosis factor- $\alpha$, platelet-derived factor, thyroid hormone and insulin-like growth factor-I (IGF-I) stimulate IL-6 production in osteoblastic cells (Littlewood et al. 1991, Slootweg et al. 1992, Franchimont \& Canalis 1995, Tarjan \& Stern 1995, Swolin \& Ohlsson 1996).

Increased levels of glucocorticoids decrease the process of bone formation in bone remodeling. One of the mechanisms for this probably involves decreasing local IGF-I production in osteoblasts. Cortisol decreases IGF-I production in rodent and human osteoblasts (Canalis et al. 1989, McCarthy et al. 1990, Delany \& Canalis 1995, Swolin et al. 1996), and IGF-I treatment of cultured human osteoblasts prevents the negative effect of high

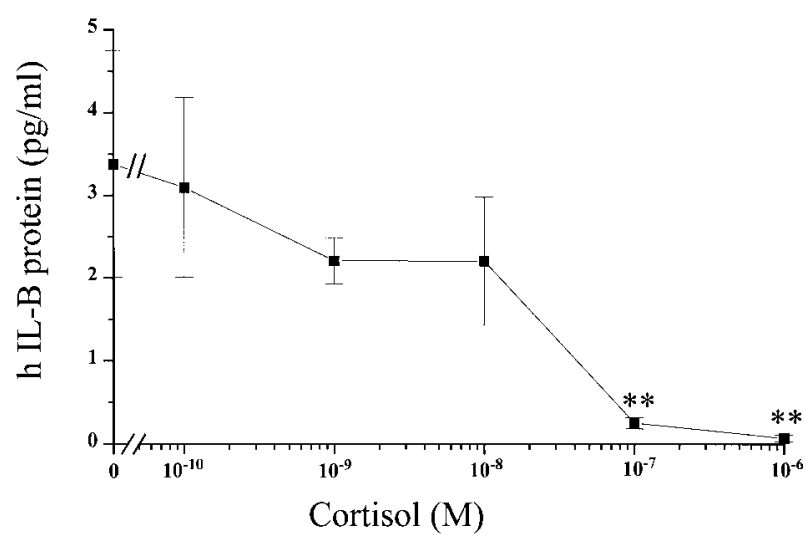

Figure 5 Dose-response effect of cortisol on hIL-1 $\beta$ protein secreted into the culture medium from rhlL-1 $\alpha(25 \mathrm{U} / \mathrm{ml})$ stimulated hOB cells from four patients (four males, 22, 32, 47 and 50 years old). Each experiment was performed using cells from one patient. The results from the four patients were then pooled. rhIL-1 $\alpha$-stimulated cells were stimulated with different doses of cortisol for $16 \mathrm{~h}$ before medium harvest. The hIL-1 $\beta$ protein was not detectable without the addition of rhIL-1 $\alpha$. Levels are expressed as $\mathrm{pg} / \mathrm{ml}$. Values are the mean \pm S.E.M. ${ }^{* *} P<0 \cdot 01$ compared with cells not treated with cortisol.

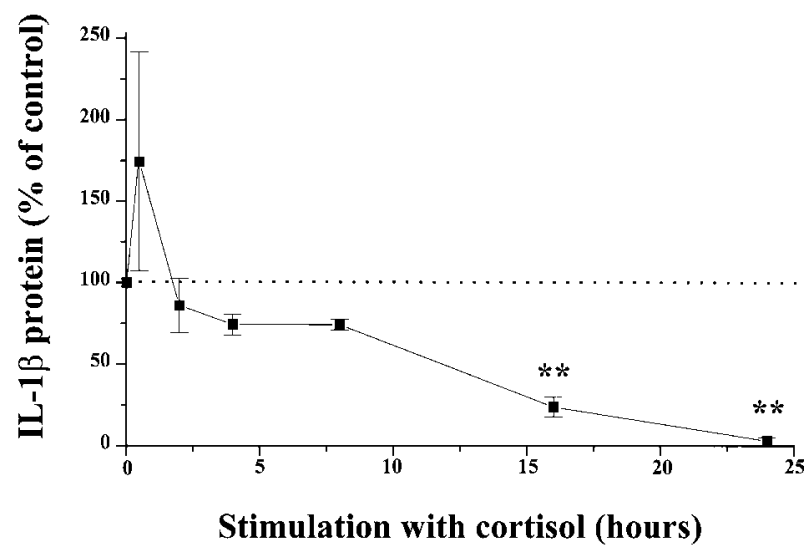

Figure 6 Time-course effect of cortisol on levels of hIL-1 $\beta$ protein released into the culture medium. Cells were cultured in 10\% FCS and starved in DMEM without phenol red with the addition of $0 \cdot 5 \%$ DCC-FCS for $24 \mathrm{~h}$. Cortisol $\left(10^{-6} \mathrm{M}\right)$ was then added at different times before harvesting of the medium. Each experiment was performed using cells from one patient. The results from three patients were then pooled. Values are expressed as \% of control levels (mean \pm S.E.M. from pooled samples from three patients (two males 26 and 41 years old and one 12-year-old female)).

${ }^{* *} P<0 \cdot 01$ compared with untreated cells.

levels of cortisol (Jonsson et al. 1993). An interaction between the decreased IL-6 expression caused by cortisol in osteoblasts, as seen in the present study, and the effect of IGF-I on bone formation is supported by the observation that IL-6 increases IGF-I expression in osteoblasts (Franchimont et al. 1996, 1997). Furthermore, IGF-Ibinding protein-5 (IGFBP-5), which is mitogenic for osteoblasts (Andress \& Birnbaum 1992, Mohan et al. 
1995), is upregulated by IL-6, and some studies demonstrate a mitogenic effect of IL-6 on osteoblasts (Fang \& Hahn 1991, Taguchi et al. 1996, Franchimont et al. 1997). Thus decreased IL-6 expression caused by cortisol in osteoblasts might have anti-mitogenic effects on osteoblasts via a reduction of IGF-I and IGFBP-5 and/or a direct inhibition of cell proliferation. An anabolic effect of IL-6 on osteoblasts is supported by the fact that mice with homologous disruption of the IL-6 gene have a decreased cortical bone volume (Poli et al. 1994). Therefore it could be speculated that the main effect in bone of decreased IL-6 expression caused by cortisol in osteoblasts is decreased bone formation, resulting in decreased bone mass. An important effect of the decreased IL- 6 expression caused by cortisol in osteoblasts on bone resorption seems less probable, as such an effect would result in increased bone mass.

It has been speculated that changes in IL-6 expression constitute one of the fundamental ageing processes and contribute to osteoporosis (Ershler 1993). Serum levels of IL-6 are known to increase with age (McKane et al. 1994). However, in the present study, no statistically significant age-correlated increase in IL-6 expression in hOB cells was seen. This indicates that the serum levels of IL-6 are instead dependent on age-dependent changes in the subject's immune or endocrine systems. However, it should be emphasized that only 15 subjects were examined in the present study.

IL-1 $\beta$ performs a variety of functions in hOB cells. It increases the proliferation and synthesis of prostaglandin $\mathrm{E}_{2}$ and plasminogen-activating factor, while it antagonizes vitamin D stimulation of alkaline phosphatase activity (Evans et al. 1990). Our results indicating that cortisol decreases IL-1 $\beta$ expression in hOB cells are similar to those previously obtained for human histiocytic lymphoma cells (Knudsen et al. 1987). Cortisol suppresses the expression of both IL-1 $\beta$ and IL-6 in hOB cells, as shown in the present study, and in human myeloma cells (Ishikawa et al. 1990). It has previously been shown that IL-1 increases IL-6 expression in osteoblasts, indicating that IL- $1 \beta$ regulates the expression of IL-6 in osteoblasts (Ishimi et al. 1990, Chaudhary et al. 1992). It is therefore possible that the cortisol-induced decrease in IL-6 was mediated via a reduction in IL-1 $\beta$. However, in our culture system, this cannot be so as the IL-6 mRNA levels decreased before a reduction in IL-1 $\beta$ was seen.

Udagawa et al. (1995) have shown that the treatment of osteoblasts with dexamethasone induced a marked increase in the expression of IL-6R mRNA and that IL-6-induced osteoclast differentiation depends on a signal transduction mediated by the IL-6R which is expressed on osteoblastic cells but not on osteoclast progenitors. IL-6R was not measured in the present study. We tried to measure sIL-6R, which is similar to the extracellular part of IL-6R, released into the culture medium. No detectable levels of sIL-6R were found in the culture medium from hOB cells when measured with an ELISA with a sensitivity of $3.5 \mathrm{pg} / \mathrm{ml}$. However, it is possible that cortisol regulates systemic levels of sIL-6R and thereby indirectly modulates the effect of IL-6 produced locally in osteoblasts.

In conclusion, this study demonstrates that high levels of cortisol strongly inhibit IL- 6 expression and IL- $1 \beta$ protein released into the culture medium in human osteoblast-like cells. It may be speculated that the decreased IL-6 expression caused by cortisol in osteoblasts results in decreased bone mass via decreased bone formation and not via modulation of bone resorption.

\section{Acknowledgements}

This work was supported by grants K95-19P-11328-01A and K96-19P11837-02B from the Swedish Medical Research Council, grants from Pharmacia \& Upjohn (Stockholm, Sweden), the Novo Nordisk Foundation (Bagsvaerd, Denmark), the Swedish Society for Medical Research, the Lundberg Foundation, and the Göteborg Medical Society. We thank A Hansevi and K Lövstedt for their excellent assistance. We would also like to thank the Department of Orthopedics, Sahlgrenska Hospital, and Dr Anders Nilsson for providing us with bone samples.

\section{References}

Andress DL \& Birnbaum RS 1992 Human osteoblast-derived insulin like growth factor (IGF) binding protein-5 stimulates osteoblast mitogenesis and potentiates IGF action. Journal of Biological Chemistry 267 22467-22472.

Black K, Garrett IR \& Mundy GR 1991 Chinese hamster ovarian cells transfected with the murine interleukin-6 gene cause hypercalcemia as well as cachexia, leukocytosis and thrombocytosis in tumor-bearing nude-mice. Endocrinology 128 2657-2659.

Canalis E \& Avioli L 1992 Effects of deflazacort on aspects of bone formation in cultures of intact calvariae and osteoblast-enriched cells. Journal of Bone and Mineral Research 7 1085-1092.

Canalis E, Centrella M, Burch W \& McCarthy TL 1989 Insulin-like growth factor I mediates selective anabolic effects of parathyroid hormone in bone cultures. Journal of Clinical Investigation 83 60-65.

Chaudhary L, Spelsberg T \& Riggs L 1992 Production of various cytokines by normal human osteoblast-like cells in response to interleukin- $1 \beta$ and tumor necrosis factor- $\alpha$ : lack of regulation by 17ß-estradiol. Endocrinology 130 2528-2534.

Chen T \& Feldman D 1979 Glucocorticoid receptors and actions in subpopulations of cultured rat bone cells. Journal of Clinical Investigation 63 750-758.

Chomczynski P \& Sacchi N 1987 Single-step method of RNA isolation by acid guanidinium thiocyanate-phenol-chloroform extraction. Analytical Biochemistry 162 156-159.

Conaway H, Grigorie D \& Lerner U 1996 Stimulation of neonatal mouse calvarial bone resorption by the glucocorticoids hydrocortisone and dexamethasone. Journal of Bone and Mineral Research 11 1419-1429.

Cushing H 1932 The basophil adenomas of the pituitary body and their clinical manifestations (pituitary basophilism). Bulletin of the Johns Hopkins Hospital 50 137-195.

Delany A \& Canalis E 1995 Transcriptional repression of insulin-like growth factor I by glucocorticoids in rat bone cells. Endocrinology 136 4776-4781. 
Delany A, Jeffrey J, Rydziel S \& Canalis E 1995 Cortisol increases interstitial collagenase expression in osteoblasts by posttranscriptional mechanisms. Journal of Biological Chemistry $\mathbf{2 7 0}$ 26607-26612.

Dinarello C 1991 Interleukin-1 and interleukin-1 antagonism. Blood 77 1627-1652.

Durnam DM \& Palmiter RD 1983 A practical approach for quantitating specific mRNAs by solution hybridization. Analytical Biochemistry 131 385-393.

Ershler W 1993 Interleukin-6: a cytokine for gerontologists. Journal of American Geriatric Society 41 176-181.

Evans DB, Bunning RA \& Russel RG 1990 The effects of recombinant human interleukin-1 $\beta$ on cellular proliferation and the production of prostaglandin $\mathrm{E}_{2}$, plasminogen activator, osteocalcin and alkaline phosphatase by osteoblast-like cells derived from human bone. Biochemical and Biophysical Research Communications 166 208-216.

Fang MA \& Hahn TJ 1991 Effects of interleukin-6 on cellular function in UMR-106-01 osteoblast-like cells. Journal of Bone and Mineral Research 6 133-139.

Feyen J, Elford P, Di Padova F \& Trechsel U 1989 Interleukin-6 is produced by bone and modulated by parathyroid hormone. Journal of Bone and Mineral Research 4 633-638.

Franchimont N \& Canalis E 1995 Platelet-derived growth factor stimulates the synthesis of interleukin-6 in cells of the osteoblast lineage. Endocrinology 136 5469-5475.

Franchimont N, Pash JM, Gabbitas B \& Canalis E 1996 Interleukin-6 in the presence of its soluble receptor stimulates insulin-like growth factor protein-5 expression in osteoblasts. Journal of Bone and Mineral Research 11 (Suppl 1) S165.

Franchimont N, Durant D \& Canalis E 1997 Interleukin-6 and its soluble receptor regulates the expression of insulin-like growth factor binding protein- 5 expression in osteoblast cultures. Endocrinology 138 3380-3386.

Gabay C, Silacci P, Genin B, Mentha G, Le Coultre C \& Guerne P-A 1995 Soluble interleukin-6 receptor strongly increases the production of acute-phase protein by hepatoma cells but exerts minimal changes on human primary hepatocytes. European Journal of Immunology 25 2378-2383.

Girasole G, Jilka RL, Passeri G, Boswell S, Boder G, Williams D \& Manolagas S 1992 17 $\beta$-Estradiol inhibits interleukin-6 production by bone-marrow derived stromal cells and osteoblasts in vitro: a potential mechanism for the antiosteoporotic effect of estrogens. Journal of Clinical Investigation 89 883-891.

Gowen M, Wood D, Ihrie E, McGuire M \& Russel G 1983 An interleukin 1 like factor stimulates bone resorption in vitro. Nature 306 378-380.

Ishikawa H, Tanaka H, Iwato K, Tanabe O, Asaoku H, Nobuyoshi M, Yamamoto I, Kawano M \& Kuramoto A 1990 Effect of glucucorticoids on the biologic activities of myeloma cells: inhibition of interleukin-1 $\beta$ osteoclast activating factor-induced bone resorption. Blood 75 715-720.

Ishimi Y, Miyaura C, Jin C, Akatsu T, Abe E, Nakamura Y, Yamaguchi A, Yoshiki S, Matsuda T, Hirano T, Kishimoto T \& Suda T 1990 IL-6 is produced by osteoblasts and induces bone resorption. Journal of Immunology 145 3297-3303.

Jonsson KB, Ljunghall S, Karlström O, Johansson AG, Mallmin H \& Ljunggren Ö 1993 Insulin-like growth factor I enhances the formation of type I collagen in hydrocortisone-treated human osteoblasts. Bioscience Reports 13 297-302.

Kassem M, Harris SA, Spelsberg T \& Riggs BL 1996 Estrogen inhibits interleukin-6 production and gene expression in a human osteoblastic cell line with high levels of estrogen receptors. Journal of Bone and Mineral Research 11 193-199.

Kishimoto T, Akira S \& Taga T 1992 Interleukin-6 and its receptor: a paradigm for cytokines. Science 258 593-597.
Knudsen PJ, Dinarello CA \& Strom TB 1987 Glucocorticoids inhibit transcriptional and post-transcriptional expression of interleukin 1 in U937 cells. Journal of Immunology 139 4129-4134.

Kopf M, Baumann H, Freer G, Freudenberg M, Lamers M, Kishimoto T, Zinkernagel R, Bluethmann H \& Köhler G 1994 Impaired immune and acute-phase responses in interleukin-6deficient mice. Nature 368 339-342.

Kurihara N, Bertolini D, Suda T, Akiyama Y \& Roodman GD 1990 IL-6 stimulates osteoclast-like multinucleated cell formation in long-term human marrow cultures by inducing IL-1 release. Journal of Immunology 144 4226-4230.

Kurihara N, Civin C \& Roodman GD 1991 Osteotropic factor responsiveness of highly purified populations of early and late precursors for human multinucleated cells expressing the osteoclast phenotype. Journal of Bone and Mineral Research 6 257-261.

Labarca C \& Paigen K 1980 A simple, rapid, and sensitive DNA assay procedure. Analytical Biochemistry 102 344-352.

Littlewood AJ, Russell J, Harvey GR, Hughes DE, Russell RGG \& Gowen M 1991 The modulation of the expression of IL-6 and its receptor in human osteoblasts in vitro. Endocrinology 129 1513-1520.

McCarthy T, Centrella M \& Canalis E 1990 Cortisol inhibits the synthesis of insulin-like growth factor-I in skeletal cells. Endocrinology 126 1569-1575.

MacDonald BR, Gallagher JA, Ahnfelt-Ronne I, Beresford JN, Gowen M \& Russel GG 1984 Effects of bovine parathyroid hormone and 1,25-dihydroxyvitamin $\mathrm{D}_{3}$ on the production of prostaglandins by cells derived from human bone. FEBS Letters 169 49-52.

McKane WR, Khosla S, Peterson JM, Egan K \& Riggs BL 1994 Circulating levels of cytokines that modulate bone resorption: effects of age and menopause in women. Journal of Bone and Mineral Research 9 1313-1318.

Mackiewicz A, Schooltink H, Heinrich PC \& Rose-John S 1992 Complex of soluble human IL-6-receptor/IL-6 up-regulates expression of acute-phase proteins. Journal of Immunology 149 2021-2027.

Mathews LS, Norstedt G \& Palmiter RD 1986 Regulation of insulin-like growth factor I gene expression by growth hormone. Proceedings of the National Academy of Sciences of the USA $\mathbf{8 3}$ 9343-9347.

Mohan S, Nakao Y, Honda Y, Landale E, Leser U, Dony C, Lang K \& Baylink DJ 1995 Studies on the mechanisms by which insulin-like growth factor (IGF) binding protein-4 (IGFBP-4) and IGFBP-5 modulate IGF actions in bone cells. Journal of Biological Chemistry 270 20424-20431.

Nilsson A, Swolin D, Enerbäck S \& Ohlsson C 1995 Expression of functional growth hormone receptors in cultured human osteoblast-like cells. Journal of Clinical Endocrinology and Metabolism 80 3483-3488.

Poli V, Balena R, Fattori E, Markatos A, Yamamoto M, Tanaka H, Ciliberto G, Rodan GA \& Costantini F 1994 Interleukin-6 deficient mice are protected from bone loss caused by estrogen depletion. EMBO Journal 13 1189-1196.

Slootweg MC, Most WW, van Beek E, Schot LPC, Papapoulos SE \& Löwik CWGM 1992 Osteoclast formation together with interleukin-6 production in mouse long bones is increased by insulin-like growth factor-1. Journal of Endocrinology 132 433-438.

Swolin D \& Ohlsson C 1996 Growth hormone increases interleukin-6 produced by human osteoblast-like cells. Journal of Clinical Endocrinology and Metabolism 81 4329-4333.

Swolin D, Brantsing C, Matejka G \& Ohlsson C 1996 Cortisol decreases IGF-I mRNA levels in human osteoblast-like cells. Journal of Endocrinology 149 397-403.

Taguchi Y, YamateT, Mocharia H, Lin SC, Vertino A, DeTogni P, Abe E \& Manolagas SC 1996 Interleukin-6 induces osteoblast differentiation in uncommitted embryonic fibroblasts (EF). Journal of Bone and Mineral Research 11 (Suppl 1) S101. 
Takahashi N, Akatsu T, Udagawa N, Sasaki T, Yamaguchi A, Moseley JM, Martin TJ \& Suda T 1988 Osteoblastic cells are involved in osteoclast formation. Endocrinology 123 2600-2602.

Tamura T, Udagawa N, Takahashi N, Miyaura C, Tanaka S, Yamada Y, Koishihara Y, Ohsugi Y, Kumaki K, Taga T, Kishimoto T \& Suda T 1993 Soluble interleukin-6 receptor triggers osteoclast formation by interleukin 6. Proceedings of the National Academy of Sciences of the USA 90 11924-11928.

Tarjan G \& Stern PH 1995 Triiodothyronine potentiates the stimulatory effects of interleukin- $1 \beta$ on bone resorption and medium interleukin-6 content in fetal rat limb bone cultures. Journal of Bone and Mineral Research 10 1321-1326.
Udagawa N, Takahashi N, Katagiri T, Tamura T, Wada S, Findlay DM, Martin TJ, Hirota H, Taga T, Kishimoto T \& Suda T 1995 Interleukin (IL)-6 induction of osteoclast differentiation depends on IL-6 receptors expressed on osteoblastic cells but not on osteoclast progenitors. Journal of Experimental Medicine 182 1461-1468.

Van Snick J 1990 Interleukin-6: an overview. Annual Reviews of Immunology 8 253-278.

Received 8 May 1997

Revised manuscript received 4 August 1997

Accepted 28 August 1997 